\title{
Perspective
}

\section{The Call for Sustainable and Resilient Policies in the COVID-19 Crisis: How Can They Be Interpreted and Implemented?}

\author{
Ortwin Renn \\ Institute for Advanced Sustainability Studies (IASS), Berliner Str. 130, 14467 Potsdam, Germany; \\ ortwin.renn@iass-potsdam.de
}

Received: 4 July 2020; Accepted: 3 August 2020; Published: 11 August 2020

\begin{abstract}
Policy advice for dealing with the Corona Crisis has been focusing on two major concepts: resilience and sustainability. The paper explores the relationship between the two terms, illustrates the various concepts that are associated with each term, and suggests an integrative approach that is based on the ideal of maintaining critical services for reaching humane living conditions for present and future generations based on fair distribution rules and inclusive governance processes.
\end{abstract}

Keywords: concepts of resilience; tensions between resilience and sustainability; post-crisis recovery; COVID-19 crisis management

\section{Introduction: Resilience and Sustainability Revisited}

When reviewing the most often repeated policy recommendations about the COVID-19 crisis over the last few weeks, two statements predominate the public discussion in almost all countries: first, the recovery of the economy should be guided by sustainability criteria or, more specifically, the UN Sustainability Development Goals (SDGs) and, secondly, societies should invest more in resilience because the most needed infrastructure, particularly referring to healthcare and social services, was clearly at and often beyond its limits during the recent crisis [1,2]. The adherence to sustainability and resilience is echoed in many comments and policy briefs, but there is little clarity about the meaning of the two terms and, in particular, about the relationship between resilience and sustainability when applied to crisis management. It is therefore useful to review the connections between the two concepts and highlight the opportunities of how these two concepts may offer guidance to political, economic, and social actors as a means to respond to present and future crises.

Exploring the relationship between resilience and sustainability, it may be useful to distinguish three major concepts relating specifically to the role of resilience in the quest for sustainability (reviews in [3-5]). The first school claims that resilience is independent of sustainability; resilience refers to a continuation of a desired service, such as electricity, fresh water, or healthcare, in times of stress $[6,7]$. Whether such a resilient strategy of designing more robust systems for vital services actually meets the goals of sustainability, such as environmental quality, circular economy, or peaceful resolution of conflicts, is not included in this understanding. In the extreme, this concept might imply that one can strive for a resilient weapon industry, which needs to continue to provide service to armies even in times of peace.

The second concept basically claims that reliance is a part of sustainability. A major advocate of this view is the Stockholm Resilience Institute [8,9]. The main claim here is that resilience is a way to sustain the functionality of services that are crucial to meeting human needs. So, both sustainability and resilience have "something to maintain" according to this understanding of the terms. The main goal is to sustain a development that evolves within the ecological and societal planetary boundaries. 
The third concept takes a more radical view: resilience is in conflict with sustainability. Sustaining the status quo and making it more resilient defies the concept of sustainability [10]. Resilience in this understanding is directed towards maintaining the given structures rather than engaging in a dynamic change system where sustainability is a dynamic goal to guide change, not to preserve stability.

Similar thoughts can be extended to the concepts of sustainability in relation to resilience (review in Savaget et al. [11]). There is the well-established distinction into the three pillars: ecological, social, and economic (sometimes augmented with cultural). There are proponents for keeping sustainability focused on ecologic quality, while others advocate more normative visions of sustainability striving for social justice among and between the generations [12]. In contrast to the sectoral and normative distinction, many scholars stress functional concepts of sustainability such as maintaining ecological services to humankind, providing economic and social services to all people regardless of whether they live today or in the future, or finding an equitable distribution rule for environmental resources, public and private goods, and social opportunities [13]. Lastly, sustainability may be associated with processes of decision-making and communication stressing equal opportunities for learning and adaptation [14]. Some sustainability definitions explicitly refer to resilience but most do not; however, they may implicitly include this concept when they focus on sustaining "something."

This common feature of "maintaining or sustaining something" may be the key to a more coherent understanding of the relationship between the two terms [15]. Almost all definitions of resilience and sustainability include the notion of sustaining something over time. With respect to resilience, it is the functionality of critical services that should be preserved even when the system is under stress; with respect to sustainability, it is the continuation of humane living conditions for present and future generations (within a co-evolution of social and natural systems). While resilience does not specify the type of services und functions that need to be maintained or quickly recovered (other than that they are critical or crucial for human societies), sustainability adds purpose to the services: they should be directed towards humane living conditions. These include respecting the boundaries of natural ecosystems and resources, meeting the basic needs of all human beings, and ensuring peaceful means of conflict resolution [16].

\section{Common Goal: Maintaining Humane Living Conditions for Present and Future Generations}

Given this overlap, the combination of resilience and sustainability could be framed as a requirement that the conditions for providing ecological services, for ensuring economic well-being, and enabling quality of life with its essential social services are to be maintained over time in full awareness of multiple constraints such as present and future resource capacities/limitations (planetary boundaries) and of the occurrence of unexpected or unlikely stressors. Meeting this goal does not imply sustaining current practices but rather fostering technical and social innovations that make it more likely that these humane conditions can be sustained and extended from the present to future generations. In this respect, resilience and sustainability share the same common vision $[17,18]$.

However, sustainability is not only about promoting resilience related to maintaining humane living conditions. There are two additional aspects that go beyond resilience. First, sustainability is based on the normative goal of intra- and intergenerational justice [19]. Societies might experience a very resilient system, but such a system may operate at the expense of the poor or any other disadvantaged group. One might include distributional justice and fairness under the rubric of humane living conditions, but it may be better to keep it as a separate component. Orienting oneself on the average level of welfare or mean quality of life obscures the fact that essential goods and services are often unfairly distributed among the affected groups and individuals. The Pareto optimality criterion that has inspired most of our economic thinking is blind for distributional effects. Therefore, for a development to be called sustainable, it is not sufficient that crucial services are sustained over time, but that these services are also equally or fairly distributed among the respective population(s). That postulate does not only apply for humans but also, to different degrees, for other creatures that share our planet [20]. 
The third and last implication of sustainability is the need to focus on process, not only on outcomes [21]. Decisions often imply painful trade-offs between conflicting goals or moral principles. The present dilemma of policymakers to find the best route between protection against the spread of COVID-19 infections and recovery of economic and social activities illustrates this point. Conflicts between values and goals are inevitable in complex decision situations. The question is: who assigns the trade-offs and how are they legitimized? A sustainable policy framework implies that such trade-offs are performed in a most democratic way based on ethical grounding [22]. Which ethical concept is being used may differ among the various cultures and traditions in the world. However, a sustainable way to resolve such conflicts is to employ due processes based on both democratic decision-making institutions and a convincing ethical argumentation. This requirement includes a public debate about the moral principles that should be applied and a process of stakeholder and public engagement in assigning and justifying trade-offs.

\section{Application to Post-Crisis Management of the COVID-19 Pandemic}

Based on this reasoning, the two major claims in the COVID-19 management debate to enhance resilience and apply sustainability goals when designing recovery projects can be translated into concrete policies [23]. First, future investments need to restore and sustain the functionality of those goods and services that enable humane living conditions for the present and future generations, in particular healthcare, attractive working opportunities, clean environment, and peaceful co-existence with fellow humans and other creatures. The UN SDGs may act as a normative guide for selecting the targets for major investment programs. With respect to the COVID-19 crisis, investment in a health care system that provides sufficient capacity even under severe stress situations, and investments in a virtual infrastructure that is capable of maintaining vital economic and social functions through Internet services in times of physical lockout are prime examples of meeting this demand.

Secondly, all measures to boost the economy and revitalize social activities need to consider the distribution of impacts among different target groups and populations [24]. Who will gain from the measure, who is likely to lose? Policymakers are well advised to look for measures that are fair to all people affected. Alternatively, compensation measures are required if negative distributional effects cannot be avoided. In the case of the COVID-19 crisis, we have witnessed that in many countries specific subgroups, particularly the poor, the elderly, and minority groups, have been hit much harder than the average citizen [25]. Furthermore, lower income groups are more at risk for unemployment, business failures, and social stress due to physical distancing [26]. A resilient and sustainable policy mix would imply that recovery measures are primarily directed to these disadvantaged groups by providing economic aid, assistance for job creation, restoring childcare programs, and open access to health care as well as other social services.

Thirdly, decisions about policy priorities, about distributing scarce resources, and about prudent strategies between conflicting goals require the inclusion of major stakeholders, in particular those who represent groups that suffer the most [27]. In the COVID-19 crisis, some of these decisions need to be taken swiftly since they are very time sensitive. Yet, consulting with representatives of major stakeholder groups, including scientific institutions, business communities, and non-governmental organizations (NGOs), can be done even under severe time pressures. Several countries, including Germany, have been good examples of how to implement an inclusive governance style in spite of time constraints [28]. At the same time, policymakers are well advised to provide a clear (ethical) justification for the necessary trade-offs that they assign between conflicting goals. Most prominent is the decision to design a middle ground between protection against the spread of the disease and the relaxation of economic and social restrictions [29]. It may be wise to determine this middle ground in light of the regional context conditions (such as number of new infections, population density, accessible heath care facilities,) but it is mandatory to come up with an ethically convincible rationale for making such trade-offs [30]. It should be transparent as to how much reduction in spreading the disease is worth how much in reducing economic or social suffering. Both an inclusive approach to 
making such painful decisions and a convincing rationale for justifying the trade-offs are not only prerequisites for a sustainable policymaking process, they are also major conditions for avoiding political polarization and public outrage.

The combination of resilience and sustainability provides effective guidance for managing global crises beyond the present COVID-19 pandemic. It can and should be applied to design policies for many other major threats such as global climate and environmental changes, collapse of financial or economic systems, or growing inequalities. Investing in resilience for sustainable infrastructures, providing access to sustainable services to all people, and implementing an inclusive, participatory governance approach are promising strategies to cope with sudden as well as slowly developing threats. COVID-19 is a wake-up call for the international community to take concrete actions to enhance resilience and sustainability worldwide.

Funding: This research received no external funding.

Acknowledgments: The author is grateful to the German Federal Ministry for Education and Research and the State Ministry for Science, Research and Culture for their continuous support for the Institute for Advanced Sustainability Studies (IASS) in Potsdam, Germany.

Conflicts of Interest: The author declares no conflict of interest. The views expressed in this paper reflect the position of the author.

\section{References}

1. Hynes, W.; Trump, B.; Love, P.; Linkov, I. Bouncing forward: A resilience approach to dealing with COVID-19 and future systemic shocks. Environ. Sys. Decis. 2020, 28, 1-11. [CrossRef]

2. Buheji, M.; Ahmed, D. Foresight of coronavirus (Covid-19): Opportunities for a better world. Am. J. Econ. 2020, 10, 97-108.

3. Reid, R.; Botterill, L.-C. The multiple meanings of 'Resilience': An overview of the literature. Austr. J. Public Adm. 2013, 72, 31-40. [CrossRef]

4. $\mathrm{Xu}, \mathrm{L}$. An integrated framework for resilience research: A systematic review based on citation network analysis. Sustain. Sci. 2018, 13, 235-254. [CrossRef]

5. IRGC. Resource Guide on Resilience; EPFL International Risk Governance Center: Lausanne, France, 2018; Volume 2.

6. Jackson, S.; Ferris, T.L.J. Resilience principles for engineered systems. Syst. Eng. 2012, 16, 152-164. [CrossRef]

7. Haimes, Y.Y. On the definition of resilience in systems. Risk Anal. 2009, 29, 498-501. [CrossRef]

8. Folke, C.; Biggs, R.; Norström, A.V.; Reyers, B.; Rockström, J. Social-ecological resilience and biosphere-based sustainability science. Ecol. Soc. 2016, 21. [CrossRef]

9. Biggs, R.; Schlüter, M.; Schoon, M.L. Principles for Building Resilience. Sustaining Ecosystem Services in Social-Ecological Systems; Cambridge University Press: Cambridge, UK, 2015.

10. van der Leeuw, S. Social Sustainability, Past and Future. Undoing Unintended Consequences for the Earth's Survival; Cambridge University Press: Cambridge, MA, USA, 2020; p. 81ff.

11. Savaget, P.; Geissoerfer, M.; Kharazzi, A.; Evans, S. The theoretical foundations of sociotechnical systems change for sustainability: A systematic literature review. J. Clean. Prod. 2019, 206, 878-892. [CrossRef]

12. Vasconcellos Oliveira, R. Back to the future: The potential of intergenerational justice for the achievement of the sustainable development goals. Sustainability 2018, 10, 427. [CrossRef]

13. Renn, O.; Jaeger, A.; Deuschle, J.; Weimer-Jehle, W. A normative-functional concept of sustainability and its indicators. Int. J. Glob. Environ. Issues 2009, 9, 291-317. [CrossRef]

14. van Mierlo, B.; Beers, P.J. Understanding and governing learning in sustainability transitions: A review. Environ. Innovn. Soc. Transit. 2020, 34, 255-269. [CrossRef]

15. Faber, M.H.; Miraglia, S.; Qin, J.; Stewart, M.G. Bridging resilience and sustainability-Decision analysis for design and management of infrastructure systems. Sustain. Resil. Infrastruct. 2020, 5, 102-124. [CrossRef]

16. Robertson, M. Sustainability: Principles and Practice, 2nd ed.; Routledge: New York, NY, USA, 2017; pp. 3-4.

17. Fiksel, J. Designing resilient, sustainable systems. Environ. Sci. Technol. 2013, 37, 5330-5339. [CrossRef] [PubMed] 
18. Rockström, J.; Steffen, W.; Noone, K.; Persson, A.; Chapin, F.S., III; Lambin, E.; Lenton, T.M.; Scheffer, M.; Folke, C.; Schellnhuber, H.J.; et al. A safe operating space for humanity. Nature 2009, 461, 472-475. [CrossRef]

19. Doorn, N. How can resilient infrastructures contribute to social justice? Preface to the special issue of sustainable and resilient infrastructure on resilience infrastructures and social justice. Sustain. Resil. Infrastruct. 2019, 4, 99-102. [CrossRef]

20. Washington, H.; Taylor, B.; Kopnina, H.; Cryer, P.; Piccolo, J.J. Why Ecocentrism is the Key pathway to Sustainability. Ecol. Citiz. 2017, 1. Available online: https://openaccess.leidenuniv.nl/bitstream/handle/1887/ 50284/WashingtonetalWhyecocentrismisthekeypathwaytosustainability2017.pdf? sequence=1 (accessed on 10 August 2020).

21. Hendriks, C. Policy design without democracy? Making democratic sense of transition management. Policy 2009, 42, 341-361. [CrossRef]

22. Voss, J.-P.; Grin, J. Designing long-term policy; rethinking transition management. Policy Sci. 2009, 42, 275-302. [CrossRef]

23. Collins, A.; Florin, M.-F.; Renn, O. COVID-19 risk governance: Drivers, responses and lessons to be learned. J. Risk Res. 2020, 2, 1-10. [CrossRef]

24. WEF, World Economic Forum. Coronavirus: A Pandemic in the Age of Inequality. 2020. Available online: www.weforum.org/agenda/2020/03/coronavirus-pandemic-inequality-among-workers (accessed on 7 June 2020).

25. Wang, Z.; Tang, K. Combating COVID-19: Health equity matters. Nat. Med. 2020, 26, 458. [CrossRef]

26. Nicola, M.; Alsafi, Z.; Sohrabi, C.; Kerwan, A.; Al-Jabir, A.; Iosifidis, C.; Agha, M.; Agha, R. The socio-economic implications of the coronavirus pandemic (COVID-19): A review. Int. J. Surg. 2020, 78, 185-193. [CrossRef]

27. Rajan, D.; Koch, K.; Rohrer, K.; Bajnockzi, C.; Socha, A.; Voss, M.; Nicod, M.; Ridde, V.; Koonin, J. Governance of the Covid-19 response: A call for more inclusive and transparent decision-making. BMJ Glob. Health 2020, 5, e002655. [CrossRef]

28. WEF, World Economic Forum. How Germany Contained the Coronavirus. The WEF Covid-19 Action Platform. 2020. Available online: https://www.weforum.org/agenda/2020/05/how-germany-contained-thecoronavirus/ (accessed on 10 August 2020).

29. OECD. OECD Economic Outlook, Interim Report March 2020: Coronavirus, the World Economy at Risk; OECD Publishing: Paris, France, 2020. Available online: https://www.oecd.org/berlin/publikationen/ Interim-Economic-Assessment-2-March-2020.pdf (accessed on 10 August 2020).

30. Khoo, E.J.; Lantos, J.D. Lessons learned from the COVID-19 pandemic. Acta Paediatr. 2020, 2, $1323-1325$. [CrossRef]

(C) 2020 by the author. Licensee MDPI, Basel, Switzerland. This article is an open access article distributed under the terms and conditions of the Creative Commons Attribution (CC BY) license (http://creativecommons.org/licenses/by/4.0/). 